\title{
FAKTOR INTERNAL YANG BERHUBUNGAN DENGAN KADAR ENZIM CHOLINESTERASE PADA DARAH PETANI KENTANG DI GAPOKTAN AL-FARRUQ DESA PATAK BANTENG KECAMATAN KEJAJAR KABUPATEN WONOSOBO TAHUN 2016
}

\author{
Aulia Bagas Wicaksono ${ }^{1)}$, Teguh Widiyanto ${ }^{2)}$, Agus Subagiyo ${ }^{3)}$ \\ Jurusan Kesehatan Lingkungan, Politeknik Kesehatan Kemenkes Semarang, \\ Jl.Raya Baturaden KM 12 Purwokerto, Indonesia
}

\begin{abstract}
Abstrak
Upaya perlindungan kesehatan masyarakat dalam Peraturan Pemerintah No 66 tahun 2014 tentang Kesehatan Lingkungan Pasal 39 dilakukan untuk mewujudkan lingkungan sehat yang bebas dari unsur yang menimbulkan gangguan kesehatan. Pasal 39 Ayat 2 huruf e menjelaskan unsur yang menimbulkan gangguan kesehatan adalah pestisida. Di Indonesia banyak terjadi kasus keracunan pestisida yaitu penurunan kadar enzim cholinesterase. Pestisida masuk kedalam tubuh manusia salah satunya melalui faktor internal. Tujuan penelitian yaitu mengetahui faktor internal yang berhubungan dengan kadar enzim cholinesterase. Metode penelitian observasional dengan desain cross sectional. Penelitian dilakukan Maret hingga Juni 2016. Populasi dan sampel penelitian yaitu total petani kentang di Gapoktan Al-Farruq dengan jumlah 38 petani kentang. Pengumpulan data dilakukan dengan wawancara, observasi, dan pemeriksaan laboraturium. Analisis univariate menggunakan distribusi frekuensi, dan bivariate menggunakan uji chi-square dengan a 5\%. Hasil penelitian menggunakan alaisis bivariat menunjukan bahwa tidak ada hubungan antara keadaan kesehatan dengan kadar enzim cholinesterase $(p=1,000)$, tidak ada hubungan antara umur dengan kadar enzim cholinesterase $(p=0,613)$, tidak ada hubungan antara jenis kelamin dengan kadar enzim cholinesterase $(p=0,226)$, tidak ada hubungan antara tingkat pendidikan dengan kadar enzim cholinesterase $(p=0,913)$, tidak ada hubungan antara pengetahuan dengan kadar enzim cholinesterase $(p=273)$. Simpulan dari hasil penelitian yaitu tidak ada hubungan antara keadaan kesehatan, umur, jenis kelamin, tingkat pendidikan, dan pengetahuan dengan kadar enzim cholinesterase. Disarankan dilakukan penyuluhan oleh dinas pertanian dan dinas kesehatan mengenai penggunaan dan penanganan pestisida yang baik.
\end{abstract}

Kata kunci $\quad$ : faktor internal, enzim cholinesterase, pestisida, keracunan

\begin{abstract}
The efforts of environmental health in Government Regulation No. 66 year 2016 about Environmental Health Article 39 is held to make healthy environment which is free from health disturbing elements. Article 39 Subsection 2 Alphabet e explains about elements which can cause disturbance of health is pesticide. In Indonesia there are many cases of poisonous pesticide caused by decreasing of cholinesterase enzyme. Pesticide is going into human body because of one internal factor. The purpose of this research is to find out internal factors correlated with cholinesterase enzyme level. The method used in this research was observational with cross setional design. The research conducted in march until june 2016. The population and sample were the total amount of potato farmers in Gapoktan Al-Farruq wich were 38 people. Data collection were obtained by interview, observation, and laboratory examination. Univariate analysis used frequency distribution, and bivariate used chi square test with a $5 \%$. The result of this research used bivariate analysis shows that there was no correlation between health condition and cholinesterase enzyme level $(p=1,000)$, no correlation between age and cholinesterase enzyme level $(p=0,613)$, no correlation between sex and cholinesterase enzyme level $(p=0,226)$, nocorrelation between education andcholinesterase enzyme level $(p=0,913)$, no correlation between knowledge and cholinesterase enzyme level $(p=273)$. The conclusion of this research is there was no correlation between the conditions of health, age, sex, education, and knowledge with cholinesterase enzyme level. The researcher suggests doing counseling by health official concerning about the right usage and handling of pesticide.
\end{abstract}

Keyword : : internal factors, cholinesterase enzyme, pesticide, poisonous

\section{PENDAHULUAN}

Upaya perlindungan kesehatan masyarakat dalam Peraturan Pemerintah No 66 tahun 2014

1) Email : auliabagaswicaksono@gmail.com

2) Email : teguhwidiyanto007@gmail.com tentang Kesehatan Lingkungan Pasal 39 dilakukan untuk mewujudkan lingkungan sehat yang bebas dari unsur yang menimbulkan 
gangguan kesehatan. Pasal 39 Ayat 2 huruf e menjelaskan unsur yang menimbulkan gangguan kesehatan adalah pestisida.

Hasil penelitian yang dilakukan oleh Imelda G.P menunjukan ada hubungan bermakna antara tingkat risiko paparan $(p=0,008)$, lama kerja $(p=0,011)$ dengan kadar cholinesterase pada perempuan usia subur di Kecamatan Kersana Kabupaten Brebes. Hasil regresi logistik menunjukkan bahwa wanita dengan tingkat risiko paparan tinggi pestisida 9,11 kali lebih besar untuk mengalami kadar cholinesterase rendah dari pada wanita dengan tingkat risiko paparan rendah.

Gapoktan Al-Farruq merupakan gabungan kelompok tani kentang yang berada di Desa Patak Banteng Kecamatan Kejajar Kabupaten Wonosobo. Hasil survey pendahuluan pada 19 petani diketahui 14 petani menggunakan pestisida golongan organofosfat dan 9 petani menggunakan pestisida golongan karbamat. Rata-rata mereka menggunakan 5-6 jenis pestisida untuk memberantas hama pada tanaman kentang. Mereka melakukan penyemprotan rata-rata 5 hari sekali saat musim kemarau dan 3 hari sekali saat musim hujan. Lama penyemprotan tergantung dari luas lahan namun sebagian besar mereka tidak menggunakan alat pelindung diri saat menyemprot.

Tujuan penelitian adalah mengetahui hubungan antara keadaan kesehata, umur, jenis kelamin, tingkat pendidikan, dan pengetahuan dengan kadar enzim cholinesterase.

\section{METODE}

Variabel bebas pada penelitian ini adalah keadaan kesehatan, umur, jenis kelamin, tingkat pendidikan, dan pengetahuan sedangkan variabel terikatnya adalah enzim cholinesterase..
Jenis penelitian ini adalah observasional dengan design crossectional. Populasi dalam penelitian ini seluruh petani kentang di Gapoktan Al-farruq dengan jumlah sampel 34 petani laki-laki dan 4 petani perempuan. Pengumpulan data dengan, pemeriksaan laboratorium, observasi, wawancara, dan pengisian kuesioener. Analisis univariat menggunakan distribusi frekuensi, bivariat menggunakan uji chi square dengan a $5 \%$.

\section{HASIL DAN PEMBAHASAN}

Analisis Univariat

\begin{tabular}{llrl} 
Tabel 1 Analisis Univariat & & & \\
\hline Variabel & Deskripsi & Frekuensi & $\%$ \\
\hline Keadaan & Sehat & 32 & 84,2 \\
kesehatan & Sakit & 6 & 15,8 \\
& & & \\
Umur & $>40$ tahun & 19 & 50 \\
& $<40$ tahun & 19 & 50 \\
& & & \\
Jenis kelamin & Laki -laki & 34 & 89,5 \\
& Perempuan & 4 & 10,5 \\
& & & \\
Tingkat & & & \\
pendidikan & Rendah & 32 & 84,2 \\
& Tinggi & 6 & 16,8 \\
Pengetahuan & Baik & & \\
& Kurang & 22 & 57,9 \\
& & 16 & 42,1 \\
\hline
\end{tabular}

\section{Keadaan Kesehatan}

Keadaan kesehatan responden pada saat pemeriksaan dengan kategori sehat sebanyak 32 orang $(84,2 \%)$ dan yang sedang dalam keadaan sakit sebanyak 6 orang (15,8\%). Chada (1995,222) menyatakan seseorang yang sedang menderita sakit akan mudah terpengaruh oleh efek racun dibandingkan dengan orang yang sehat. Berdasarkan hal tersebut maka 6 responden memiliki resiko lebih besar mengalami penurunan kadar enzim cholinesterase karena saat penelitian sedang dalam keadaan sakit dan berdasarkan hasil wawancara diketahui saat bekerja mereka mengalami keluhan seperti pusing, mual, muntah, dan pingsan.

\section{Umur}

Jumlah responden dengan umur $>40$ tahun sebanyak 19 orang (50\%) dan responden pada usia $<40$ tahun sebanyak 19 orang (50\%). Semakin bertambahnya umur seseorang semakin banyak yang dialaminya, dan semakin banyak pula pemaparan yang dialaminya, dengan bertambahnya umur seseorang maka fungsi metabolisme akan menurun dan berakibat menurunnya aktifitas cholinesterase sehingga akan mepermudah terjadinya keracunan pestisida. Usia juga berkaitan dengan kekebalan 
tubuh dalam mengatasi tingkat tokisisitas suatu zat, semakin tua umur seseorang maka efektifitas sistem kekebalan didalam tubuh akan semakin berkurang (Arisman, 2004). Berdasarkan hal tersebut maka 19 responden yang memiliki umur $>40$ tahun memiliki resiko lebih besar mengalami penurunan enzim cholinesterase.

\section{Jenis Kelamin}

Jumlah responden laki-laki yaitu 34 orang lebih banyak dari responden perempuan yaitu 4 orang. Jenis kelamin laki-laki dan wanita mempunyai angka normal aktivitas cholinesterase yang berbeda. Kadar kholin bebas dalam plasma laki-laki dewasa normal rata-rata sekitar $4,4 \mu \mathrm{g} / \mathrm{ml}$. Kaum wanita rata-rata mempunyai aktifitas khlinesterase darah lebih tinggi dibandingkan dengan laki-laki. Meskipun demikian tidak dianjurkan wanita menyemprot pestisida, karena pada saat kehamilan kadar rata-rata kholinesterase cenderung turun. (Afriyanto, 2008).

\section{Tingkat Pendidikan}

Responden dengan kategori pendidikan rendah yaitu 32 orang lebih banyak dari responden dengan kategori pendidikan tinggi. Pendidikan formal yang diperoleh seseorang akan memberikan tambah pengetahuan bagi individu tersebut, dengan tinkgkat pendidikan yang lebih tinggi diharapkan pengetahuan tentang pestisida dan bahayanya juga lebih baik jika dibandingkan dengan tingkat pendidikan yang rendah sehingga dalam pengelolaan pestisida, tingkat pendidikan tinggi akan lebih baik (Achmadi, 2005). Berdasarkan hal tersebut maka 32 responden memiliki resiko lebih besar mengalami penurunan enzim cholinesterase karena termasuk dalam kategori pendidikan rendah.

\section{Pengetahuan}

Responden yang memiliki pengetahuan baik yaitu 22 orang (57,9\%) lebih banyak dari responden yang memiliki pengetahuan kurang yaitu 16 orang (42,1\%). Tingkat pengetahuan merupakan faktor penunjang dalam bersikap dan melaksanakan aktivitas (praktik) karena pengetahuan adalah salah satu faktor pertama dalam perilaku. Pengetahuan dan kognitif merupakan domain yang sangat penting untuk terbentuknya tindakan seseorang. Berdasarkan hasil pengalaman dan penelitian terbukti bahwa perilaku yang di dasari oleh pengetahuan akan lebih dapat di lihat secata langsung dari perilaku yang tidak di dasari oleh pengetahun (Notoatmojo, 1993).

Green (1997) berpendapat bahwa pengetahuan merupakan faktor yang penting dalam perubahan perilaku. Oleh karena itu pengetahuan penggunaan dan pengelolaan pestisida berdampak terhadap penurunan aktivitas cholinesterse darah karena adanya praktek penggunaan dan pengelolaan pestisida yang merupakan salah satu akibat dari kurangnya pengetahuan akan berdampak terhadap praktek. Berdasarkan hall tersebut, maka 16 responden memiliki resiko lebih besar mengalami penurunan enzim cholinesterase karena memiliki pengetahuan tentang pestisida yang rendah.

\section{Analisis Bivariat}

\section{Hubungan antara keadaan kesehatan dengan kadar enzim cholinesterase}

Tabel 2 menunjukkan tidak ada hubungan antara keadaan kesehatan dengan kadar enzim cholinesterase (pvalue $=0,145$ ). Hasil Penelitian ini berbeda dengan peneltian Agung Rosyid Budiawan (2014) di Kabupaten Pati yang menyatakan ada hubungan antara status kesehatan dengan kadar enzim cholinesterase dengan ( $\mathrm{p}$ value $=0,001$ ).

Berdasarkan penelitian dilapangan setelah penyemprotan petani sering mengeluh mual pusing dan bahkan ada yang sampai muntah karena saat melakukan penyemprotan mereka tidak menggunakan APD yang lengkap terutama masker dan sarung tangan selain itu terdapat petani yang merokok saat menyemprot dan mereka membawa makanan dan minuman ke ladang. Setelah penyemprotan mereka biasanya makan makanan yang mereka bawa. Hal ini dapat mempengaruhi status kesehatan petani karena kebersihan dan hygene perorangan yang kurang baik, ini disebabkan mereka hanya mencuci tangan diarea persawahan tanpa menggunakan sabun sehingga dapat terjadi keracunan melalui portal entry.

Portal entry ini sering dan mudah terjadi namun bahan asing yang masuk tidak akan mudah mencapai peredaran darah karena beberapa hal penting yang terkait pada fungsi saluran gastrointestinal. Di mulut xenobiotik bercampur dengan ludah yang mengandung enzim, di dalam lambung xenobiotik yang tidak tahan asam akan dihancurkan oleh asam lambung, di usus halus akan bertemu dengan enzim usus halus yang bersifat basa sehingga xenobiotik asam akan ternetralisir, dan seterusnya hingga terbuang melalui usus besar. Proses absorbsi terjadi melalui mukosa usus, yang selanjutnya mengalir mengikuti system sirkulasi darah. (Suwindre, 1993 dalam Rustia, 2009)

Setiap petani sebaiknya manjaga kondisi kesehatan dan gizi dirinya misalnya dengan makan makanan yang bergizi dan hygene agar terhindar dari sakit. Petani juga sebaiknya rutin memeriksakan kesehatan minimal satu bulan sekali ke Puskesmas atau klinik kesehatan.

Tabel 1 Analisis Univariat 


\begin{tabular}{|c|c|c|c|c|c|c|c|c|}
\hline \multirow{2}{*}{ No } & \multirow{2}{*}{ Variabel } & \multicolumn{4}{|c|}{ Kejadian keracunan } & \multirow[b]{2}{*}{ Total } & \multirow[t]{2}{*}{$\%$} & \multirow[b]{2}{*}{$p-v t$} \\
\hline & & Keracunan & $\%$ & Normal & $\%$ & & & \\
\hline \multirow[t]{3}{*}{1} & Keadaan kesehatan & & & & & & & \\
\hline & Sakit & 5 & 83,3 & 1 & 16,7 & 6 & 100 & 0,1 \\
\hline & Sehat & 16 & 50 & 16 & 50 & 32 & 100 & \\
\hline \multirow[t]{3}{*}{2} & Umur & & & & & & & \\
\hline & $>40$ tahun & 11 & 57,9 & 8 & 42,1 & 19 & 100 & $1, \mathrm{C}$ \\
\hline & $<40$ tahun & 10 & 52,6 & 9 & 47,4 & 19 & 100 & \\
\hline \multirow[t]{3}{*}{3} & Jenis Kelamin & & & & & & & \\
\hline & Laki-laki & 20 & 58,8 & 14 & 41,2 & 34 & 100 & 0,3 \\
\hline & Perempuan & 1 & 25 & 3 & 75 & 4 & 100 & \\
\hline \multirow[t]{3}{*}{4} & Tingkat pendidikan & & & & & & & \\
\hline & Rendah & 18 & 56,3 & 14 & 43,8 & 32 & 100 & $1, \mathrm{C}$ \\
\hline & Tinggi & 3 & 50 & 3 & 50 & 6 & 100 & \\
\hline \multirow[t]{3}{*}{5} & Pengetahuan & & & & & & & \\
\hline & Kurang & 11 & 68,8 & 5 & 32,1 & 16 & 100 & 0,2 \\
\hline & Baik & 10 & 45,5 & 12 & 54,5 & 22 & 100 & \\
\hline
\end{tabular}

Hubungan antara umur dengan kadar enzim cholinesterase

Pada penelitian ini proporsi terjadi penurunan enzim cholinesterase kurang dari 75\% lebih banyak terjadi pada kategori umur lebih dari 40 tahun, namun pada umur kurang dari 40 tahun tidak jauh berbeda jumlah yang mengalami penurunan kadar enzim cholinesterase. Hal tersebut sesuai dengan teori yang menyatakan bahwa seiring pertambahan umur maka fungsi metabolisme tubuh juga menurun. Semakin bertambahnya umur seseorang semakin banyak yang dialaminya, dan semakin banyak pula pemaparan yang dapat terjadi. Dengan bertambahnya umur sesorang maka fungsi metabolisme akan menurun dan ini juga akan berakibat menurunya aktifitas cholinesterase darahnya sehingga akan mempermudah terjadinya keracunan pestisida. Umur juga berkaitan dengan kekebalan tubuh dalam mengatasi tingkat toksisitas suatu zat, semakin tua umur seseorang maka efektifitas system kekebalan di dalam tubuh akan semakin berkurang (Arisman 2004).

Aktivitas cholinesterase pada anakanak dan orang dewasa atau umur diatas 20 tahun mempunyai perbedaan, baik dalam keadaan tidak berkerja dengan pestisida organopospat maupun selama berkerja dengan organopospat. Umur yang masih dibawah 18 tahun merupakan kontra indikasi bagi tenaga yang berkerja dengan pestisida organopospat, karena akan memperberat terjadinya keracunan menurun aktivitas cholinesterase (Labour,1975 dalam Suhenda 2006). Hasil penelitian yang dilakukan oleh (Achmadi 1985) dinyatakan bahwa ada hubungan bermakna antara kadar kolinesterase dengan umur untuk jenis kelamin dimana yang berumur tua kadar kolinesterase cenderung rendah.

Hasil uji statistik menggunakan chisquare diperoleh hasil $(p$ value $=1,000)$ hal ini berarti bahwa tidak ada hubungan antara umur dengan kadar enzim cholinesterase. Hal tersebut karena di lapangan aktifitas petani baik kategori umur tua maupun muda tidak jauh berbeda seperti pencampuran berbagai macam merek pestisida dan bekerja tidak menggunakan APD. Masingmasing pestisida mempunyai efek fisiologis yang berbeda-beda tergantung dari kandungan zat aktif dan sifat fisik dari pestisida tersebut. Pada saat penyemprotan penggunaan pestisida $\geq 3$ jenis dapat mengakibatkan keracunan pada petani. Banyaknya pestisida yang digunakan menyebabkan beragamnya paparan pada tubuh petani yang mengakibatkan reaksi sinergik dalam tubuh ditamabah dalam bekerja menggunakan APD yang tidak lengkap(Djojosumarto, 2000 hal 23).

Penelitian ini sejalan dengan penelitian Imelda GP (2009) di Kabupaten Brebes yang menyatakan bahwa tidak ada hubungan yang signifikan antara umur dengan kadar enzim cholinesterase pada perempuan usia subur dengan $(p$ value $=0,053)$ dan $(r=0,233)$ dan penelitian yang dilakukan oleh Nana Mulyani (2011) di Kabupaten Brebes yang menyatakan bahwa tidak ada hubungan yang signifikan antara umur dengan aktivitas enzim cholinesterase darah pada petani bawang merah di Desa Tegalgandu Kecamatan Wanasari Kabupaten Brebes dengan ( $p$ value $=0,537$ ). 
Sebaiknya petani yang usianya diatas 40 tahun untuk lebih memperbanyak waktu istirahat pada saat penyemprotan agar mengurangi resiko terjadinya keracunan pestisida berupa penurunan enzim cholinesterase, yang dapat mengakibatkan gangguan pada otot manusia. Petani yang berkerja menyemprot menggunakan bahan pestisida juga harus memakai alat pelindung diri minimal masker, sarung tangan dan pakaian panjang untuk mengurangi resiko paparan oleh pestisida. Pemerintah dalam kaitannya Dinas Pertanian atau Dinas Kesehatan memberikan penyuluhan serta dapat membantu memberikan alat pelindung diri secara gratis.

\section{Hubungan antara jenis kelamin dengan kadar enzim cholinesterase}

Jenis kelamin responden laki-laki sebanyak 34 orang sedangkan perempuan sebanyak 4 orang. Berdasarkan uji chisquare diperoleh hasil ( $p$ value $=0,307)$ yang berarti tidak ada hubungan anatara jenis kelamin dengan kadar enzim cholinesterase. Hal ini dapat dijelaskan karena dalam penelitian ini responden yang diperiksa sebagian besar adalah lakilaki. Penelitian ini sejalan dengan penelitian yang dilakuakan oleh Zuraida (2011) yang menatakan bahwa tidak ada hubungan bermakna antara jenis kelamin dengan tingkat keracunan pestisida. Ini diperkuat oleh penelitian Kuat Prabowo (2002) yang menyatakan tidak ada hubungan bermakna antara jenis kelamin dengan aktivitas kolinesterase dalam Zuraida (2011).Namun tidak sesuai dengan disertasi Achmadi (1985) dalam Ruhendi (2007), yang menyatakan terdapat perbedaan bermakna aktivitas kolinesterase darah antara perempuan dan laki-laki pada petani penyemprot hama tanaman pengguna pestisida.
Tidak ada hubungan jenis kelamin dengan penurunan enzim cholinesterase karena dalam bekerja dengan pestisida, jenis pekerjaan antara laki-laki dan perempuan tidak berbeda. Dalam penyemprotan dilapangan, perempuan bertugas mengatur selang dan mereka berjalan berada dibelakang petani laki-laki saat penyemrotan. Sehingga mereka dapat mengalami penurunan enzim cholinesterase dikarenaka mereka memiliki kontak yang dekat dengan pestisida seperti petani laki-laki dan dalam bekerja baik laki-laki maupun perempuan jarang yang menggunakan masker. Pengaplikasian pestisida dengan cara disemprotkan, dimungkinkan butir-butir cairan tersebut melayang, menyimpang dari aplikasi. Jarak yang ditempuh oleh butiran-butiran cairan tergantung pada ukuran butiran. Butiran dengan radius kecil dari satu micron, dapat dianggap sebagai gas yang kecepatan mengendapnya tak terhingga, sedang butiran dengan radius yang lebih besar akan lebih cepat mengendap (Sudarmo, 1991).

Meskipun hasil penelitian menyatakan tidak ada hubungan antara jenis kelamin dengan kadar enzim cholinesterase sebaiknya hanya petani laki-laki yang berkerja menyemprot diladang karena jenis kelamin antara lakilaki dan perempuan mempunyai angka normal aktivitas cholinesterase yang berbeda. Pekerja perempuan yang berhubungan dengan pestisida organopospat, lebih-lebih dalam keadaan hamil akan mempengaruhi derajat penurunan aktivitas cholinesterase (Rustia 2009).

\section{Hubungan antara tingkat pendidikan dengan kadar enzim cholinesterase \\ Tingkat pendidikan dibagi menjadi dua kategori yaitu tinggi dan rendah dimana responden dengan kategori tinggi adalah responden yang memiliki tingkat pendidikan akhir SMA dan Perguruan Tinggi sedangkan}


responden dengan kategori rendah adalah yang memiliki tingkat pendidikan akhir SD dan SMP. Jumlah responden dengan tingkat pendidikan rendah sangat mendominasi yang berjumlah 32 orang, kondisi ini akan berpengaruh pada pola pikir masyarakat. Masyarakat petani yang masih tradisional sering dicirikan dengan tingkat pendidikan yang rendah (Rario, 2005). Berdasarkan uji chi-square diperoleh hasil ( $p$ value $=1,000$ ) yang berarti tidak ada hubungan antara tingkat pendidikan dengan kadar enzim cholinesterase. Hasil penelitian menunjukkan responden yang berpendidikan tinggi maupun rendah menggunakan pestisida sesuai aturan namun berdasarkan kebiasaan dimasyarakat seperti menggunakan dosis tidak sesuai anjuran label namun sesuai kebutuhan dan melakukan aplikasi pestisida dengan sistem kalender yaitu aplikasian pestisida secara terjadwal seperti melakukan penyemprotan seminggu dua minggu sekali saat musim kemarau dan dua hari sekali saat musim hujan. Pada sistem aplikasi kalender ini, responden menggunakan jenis insektisida dan fungisida secara bersama-sama (dicampur). Penyemprotan dengan system kalender sebenarnya merupakan salah satu dari aplikasi preventif, bersifat untunguntungan (hama belum tentu datang), cenderung boros (karena tidak ada hamapun disemprot) dan beresiko besar (bagi pengguna, konsumen, dan lingkungan) (Direktorat Jenderal Prasarana dan Sarana Pertanian, 2011).

Penelitian ini sesuai dengan penelitian Irnawati dan Arlinda (2005) di Kabupaten Simalungun bahwa tidak ada hubungan antara tingkat pendidikan dengan keracunan pestisida dimana keracunan pestisida ditunjukan dengan penurunan aktifitas enzim cholinesterase. Selain itu penelitian ini juga sejalan dengan penelitian yang dilakukan oleh Nana Mulyani (2011) yang menyatakan bahwa bahwa tidak ada hubungan antara tingkat pendidikan dengan aktivitas enzim cholinesterase darah dengan ( $p$ value $=$ 0,420).

Petani yang tingkat pendidikannya lebih tinggi sebaiknya memberikan ilmu yang dimiliki kepada petani yang pendidikannya lebih rendah guna meningkatkan pengetahuan pestisida pada petani. Pendidikan adalah upaya persuasi atau pembelajaran kepada masyarakat agar mau melakukan tindakan tindakan (praktik) untuk memelihara (mengatasi masalah-masalah) dalam kehidupan. Pendidikan formal maupun informal yang diperoleh seseorang akan memberikan tambahan pengetahuan, dengan tingkat pendidikan yang tinggi diharapkan pengetahuan tentang penggunaan pestisida dan cara mengatasi jika terjadi keracunan pestisida akan lebih baik jika disbanding dengan tingkat pendidikan yang rendah.

\section{Hubungan antara pengetahuan dengan kadar enzim cholinesterase}

Pengetahuan petani berada pada rentang $20 \%$ sampai $100 \%$ kategori seorang petani dikatakan memiliki pengetahuan yang baik apabila memiliki nilai lebih dari $75 \%$. Proporsi petani yang memiliki tingkat pengetahuan baik lebih banyak dibandingkan dengan petani kentang yang memiliki pengetahuan buruk. Walaupun di Gapoktan Al-Farruq petani kentang tidak pernah mendapatkan penyuluhan mengenai penggunaan pestisida yang baik dan benar, namun berdasarkan hasil wawancara diketahui bahwa mereka rutin mengadakan pertemuan internal rutin selama dua kali dalam satu bulan dimana dalam pertemuan tersebut antar petani melakukan komunikasi atau berbagi mengenai pengalaman mereka dalam 
penggunaan pestisida dan bahaya dari masingmasing bahan aktif pestisida.

Hasil uji statistik menggunakan chisquare diperoleh hasil ( $p$ value $=0,273$ ) yang artinya tidak ada hubungan antara pengetahuan dengan kadar enzim cholinesterase pada darah petani kentang hal tersebut dikarenakan petani yang memiliki pengetahuan baik namun memiliki sikap yang buruk saat praktik kerja dengan pestisida. Hasil penelitian ini berbeda dengan pendapat Green (1997) yang menyatakan bahwa pengetahuan merupakan faktor yang penting dalam perubahan perilaku. Oleh karena itu pengetahuan penggunaan dan pengelolaan pestisida berdampak terhadap penurunan aktivitas cholinesterse darah karena adanya praktek penggunaan dan pengelolaan pestisida yang merupakan salah satu akibat dari kurangnya pengetahuan akan berdampak terhadap praktek.

Penelitian ini sejalan dengan penelitian Nana Mulyani (2011) yang menyatakan bahwa tidak ada hubungan yang signifikan antara tingkat pengetahuan dengan aktivitas enzim cholinesterase darah pada petani bawang merah di Desa Tegalgandu Kecamatan Wanasari Kabupaten Brebes dengan ( $p$ value $=0,585$ ).

Pengetahuan sikap dan praktek (tindakan), seseorang telah setuju terhadap objek, maka akan terbentuk pula sikap positif terhadap obyek yang sama. Apabila sikap positif terhadap suatu program atau obyek telah terbentuk, maka diharapkan akan terbentuk niat untuk melakukan program tersebut. Bila niat itu betul-betul dilakukan, hal ini sangat bergantung dari beberapa aspek seperti tersediannya sarana dan prasarana serta kemudahankemudahan lainnya, serta pandangan orang lain disekitarnya. Niat untuk melakukan tindakan, misalnya menggunakan alat pelindung diri secara baik dan benar pada saat melakukan penyemproan pestisida, seharusnya sudah tersedia dan praktis sehingga petani mau menggunakannya. Hal ini merupakan dorongan untuk melakukan tindakan secara tepat sesuai aturan kesehatan sehingga risiko terjadinya keacunan pestisida dapat dicegah atau dikurangi (Wudianto,2008).

Hasil observasi dilapangan diketahui terdapat petani yang tidak menggunakan alat pelindung diri saat menyemprot, penggunaan dosis pestisida yang tidak sesuai anjuran dan terdapat petani yang menyemprot sambil merokok. Pestisida merupakan racun namun pengetahuan petani tentang pestisida yang aman masih terbatas dan belum dibuktikan dalam praktek kerja, sehingga penyuluhan tentang penggunaan pestisida yang aman perlu diadakan. Hasil analisis menunjukkan bahwa petani yang mengatakan telah mendapat penyuluhan mengenai pestisida hanya sebanyak $32,1 \%$ sedangkan sisanya tidak pernah. Sebaiknya petugas penyuluh pertanian Kecamatan Kejajar memberikan penyuluhan mengenai penggunaan pestisida yang aman dan mendampingi praktik kerja petani setelah penyuluhan.

\section{SIMPULAN DAN SARAN}

\section{Simpulan}

Faktor internal yang dapat mempengaruhi kadar e nzim cholinesterase dalam darah petani antara lain keadaan kesehatan, umur, jenis kelamin, tingkat pendidikan, pengetahuan. Hasil analisis bivariat menggunakan uji chi-square didapatkan hasil tidak ada hubungan antara keadaan kesehatan, umur, jenis kelamin, tingkat pendidikan, dan pengetahuan dengan kadar enzim cholinesterase. 21 orang (55,3\%) yang mengalami keracunan yaitu dengan kadar enzim 
cholinesterase kurang dari $75 \%$ dan 17 orang $(44,7)$ terbukti normal yaitu dengan kadar enzim cholinesterase lebih dari sama dengan $75 \%$.

\section{Saran}

Perlu adanya pemeriksaan kadar enzim kholinseterase secara periodik oleh petugas kesehatan, penyuluhan penggunaan pestisida yang aman oleh petugas penyuluh pertanian, petani menggunakan APD yang lengkap saat bekerja dengan pestisida dan peneliti selanjutnya lebih baik menambah jumlah responden dan menambah dengan factor eksternal.

\section{DAFTAR PUSTAKA}

Achmadi, UF. (1992). Aspek Kesehatan Kerja Sektor Informal . Jakarta : Depkes RI.

2005, Manajemen Penyakit Berbasis Wilayah. Jakarta: Kompas

Afriyanto,2008. Kajian Keracunan Pestisida pada Petani Penyemprota Cabe di Desa Candi Kecamatan Bandungan Kabupaten Magelang. Tesis Program Pasca Sarjana Universitas Diponegoro Semarang

Agung R, 2014, Faktor Resiko Yang Berhubungan Dengan Cholinesterase Pada Petani Bawang Merah Di Ngurensiti Pati. Jurnal IImu Kesehatan Masyarakat Universitas Negeri Semarang

Arisman, Gizi dalam Daur Kehidupan, Penebit Buku Kedokteran EGC, Jakarta, 2004

Chadha,1995, Ilmu forensik, Jakarta: Widia Medika
Djojosumarto, P. 2008, Teknik Aplikasi Pestisida Pertanian. Yoagyakarta: Kanisius.

Ekha I. 1998, Dilema Pestisida. Yogyakarta : Kanisius

Gernaulipurba I, 2009. “Analisis Faktor- Faktor Yang Berhubungan Dengan Kadar Kolinesterase Pada Perempuan Usia Subur di Daerah Pertanian” Dalam Tesis Undip Semarang

Green H, Lowrence, 1975. Perencanaan Pendidikan Kesehatan Sebuah Pendekatan Diagnostik Departemen P\&K, Jakarta.

Hidayat Natawigena, 1985, Pestisida dan Kegunaannya, Bandung: CV.Armico

Nana Mulyani, 2011. "Studi Faktor - Faktor Yang Berhubungan Dengan Aktivitas Enzim Cholinesterase Darah Pada Petani Bawang Merah Di Desa Tegalgandu Kecamatan Wanasari Kabupaten Brebes" KTI Poltekkes Semarang

Prihadi. 2007, Faktor-Faktor yang Berhubungan dengan Efek Kronis Keracunan Pestisida Organofosfat pada Petani Sayuran di Kecamatan Ngablak Kabupaten Magelang. Tesis. Semarang : Program Studi Magister Kesehatan Lingkungan Universitas Diponegoro

Prijanto TB. 2009. Analisis Faktor Resiko Keracunan Pestisida Organofosfat pada Keluarga Petani Hortikultura di Kecamatan Ngablak Kabupaten Magelang. Tesis. Semarang: Program Studi Magister Kesehatan Lingkungan Universitas Diponegoro

Rario B kasto dan S ritohardoyo, 2005. Presepsi dan Perilaku Petani Dalam Penanganan Risiko Pestisida pada Lingkungan di 
Kelurahan Kalampangan, Kecamatan Sabangau Kota Palangkaraya. Jurnal Manusia dan Lingkungan.. Pusat Studi Lingkungan Hidup Universitas Gadjah Mada. Yogyakarta

Ruhendi, Dedi (2007). Faktor-Faktor Yang Berhubungan Dengan Aktivitas Kholinesterase Darah Pada Petani Penyemprot Hama Tanaman Holtikultura Di Kabupaten Majalengka Tahun 2007. Dalam tesis Fakultas Kesehatan Masyarakat Universitas Indonesia

Rustia, Hana Nika (2009). Pengaruh Pajanan Pestisida Golongan Organopospat terhadap penurunan Aktivitas Enzim Cholinesterase dalam darah Petani Sayuran Penyemprot Pestisida(Kelurahan Campang, Kecamatan Gisting Kabupaten Tanggamus, Lampung Tahun 2009). Dalam skripsi Fakultas Kesehatan Masyarakat Universitas Indonesia

Soemirat J. 2003, Toksikologi Lingkungan, Yogayakarta : Gadjah Mada University Press

Solihun, Wawancara Januari 2016. "Wawancara Pemakaian Pestisida pada Petani Kentang Gapoktan Al- Farruq". Desa
Patak Banteng Subiyakto S, 1995, Pestisida cetakan 1995, Yogyakarta : Penerbit KANISIUS (Anggota IKAPI) 2007, Pestisida, Yogyakarta: Kanisius

Suhenda, Dadang (2006). Karakteristik Individu,Waktu Penyemprotan Terakhir, Pengetahuan, Perilaku dan Kadar Cholinesterase Darah Petani di Kabpaten Subang Tahun 2006. Fakultas Kesehatan Masyarakat Universitas Indonesia

Tampudu S,dkk. 2010, Gambaran Kadar Cholinesterase Darah Petani Penyemprot Pestisida Di Desa Minasa Baji Kab. Maros

Wudianto R. 2008. Petunjuk Penggunaan Pestisida. Jakarta : Swadaya

Yodenca A.R. 2008, Faktor-Faktor yang Berhubungan dengan Keracunan Pestisida Organofosfat, Karbamat dan Kejadian Anemia pada Petani Hortikultura di Desa Tejosari Kecamatan Ngablak kabupaten Magelang. Tesis. Semarang: Program Studi Magister Kesehatan Lingkungan Universitas Diponegoro 